\title{
Teacher's Ability to Develop Learning Materials Potentially Mathematical Discourse
}

\author{
Hamdani \\ Tanjungpura University, Pontianak, Indonesia \\ E-mail: dhamdani65@gmail.com
}

\begin{abstract}
In the process of learning in the field, the teacher still dominates the conversation while the students as a passive listener. As a result, not only the communication skills of students who are less developed, the understanding of student material is also lacking. Therefore it is necessary to research the ability of teachers in developing learning tools potentially mathematical discourse to improve students' mathematical communication skills. The research method used is descriptive. Research activities include: identification of problems through questionnaires, observation, and interviews; teacher training; teachers develop learning tools; validation; and enhancement of the device by the teacher. The subject of this research is the junior high school mathematics teacher from several districts in the border area of Sambas-Sarawak Regency. The results show that in every learning mathematics there is always a conversation between teachers and students, but rarely use the question "why" and "how". Most teacher-made lesson plans contain scenarios of conversations between teachers and students, but just plain questioning, have not led to a debate between each other so that understanding becomes deeper. Student worksheet made by the teacher in the form of a matter of the ordinary story, rarely load non-routine problem let alone open-ended.
\end{abstract}

Keywords: Mathematical Discourse; Learning Materials; Communication Skills

\section{INTRODUCTION}

One of the capabilities needed in the $21 \mathrm{st}$ century is the ability to communicate effectively both oral and written. Therefore, in learning mathematics, every teacher is expected to develop it. NCTM (2000: 60) suggests that communication is an essential element of mathematics and mathematics education because it is the "way of sharing ideas and clarifying understanding. Through communication, ideas become objects of reflection, refinement, discussion, and amendment. The communication process helps build meaning and permanence for ideas and make them public ". The 2003 TIMSS data presented in a seminar of mathematics learning at P4TK Mathematics Yogyakarta, 15-16 March 2007 that the emphasis on mathematics learning in Indonesia is more on mastery of basic skills, but little or no emphasis on mathematical communication. During teaching, the teacher speaks more than the students, and the questions given are only routine questions. Development of communication skills among students will not be optimal if not facilitated by supporting learning. The lesson in question is that it provides an opportunity for students to learn, summarize, and demonstrate their mathematical understanding through communication (mathematical discourse).

Mathematical discourse (mathematical discourse) is a conversation or a mathematical discussion. Conversation is not the same as the activity that is often done by teachers in the form of question and answer or discussion in learning mathematics, but more than that. NCTM (2000) states that "the discourse of the learning community refers to the engagement of thinking and learning" (p.16). In mathematics learning which takes place in mathematical discourse, there will be an exchange of ideas between teacher and students as well as between students and students. "Asking students to talk about mathematical concepts, procedures, and 


\section{Journal of Education, Teaching and Learning \\ Volume 2 No 2 September 2017. Page Number 177-182 \\ p-ISSN: 2477-5924 e-ISSN: 2477-4878}

problem solving helps them understand more deeply and with greater clarity" (Chapin, O'Connor, \& Anderson, 2003: 7). This is understandable because when students give reasons, communicate alternative ways to get the right answer, they are given the opportunity to get similar and different solutions. This activity is a reflection activity which, according to Yackel \& Cobb (1996), is a high-level thinking that will improve mathematical understanding. In addition, students' explanations become "starting point" for the class to develop mathematical arguments that support, expand, or perhaps argue (Whitenack \& Yackel, 2002: 524).

Chapin, O'Connor, and Anderson (2003, p.105-107) describe some of the principles of how to start a mathematical discourse in the setting of learning. First and foremost the class should "establish and maintain a respectful, supportive environment," meaning that students do not laugh at different ideas/opinions. The classroom can give consequences to disrespectful behavior to ensure that rules are enforced. If students feel in an uncomfortable learning environment, they will not participate and mathematical discourse will be limited. Another principle is "focus [the] talk on the mathematics". In addition, it is recommended to "provide for equitable participation in classroom talk". Students need to know that they are responsible for being an active participant. It is not justified for a student to dominate the discussion. In the meantime, Clarck, et al (2005) suggests 4 (four) strategies for building and maintaining mathematical discourse:

- Ask rich tasks that advance the discussion

The provision of rich mathematics tasks according to NCTM (2000) is a key ingredient in the classroom where communication is the primary goal. Open-ended and challenging tasks that build prior knowledge are conducive to the discussion because it encourages students to think and build ideas together (Stein, Smith, Henningsen, \& Silver, 2000). The tasks must accommodate the various levels that allow students of different backgrounds of knowledge and mathematical ability to solve them jointly (Cohen, 1984).

- Build and maintain a comfortable environment A comfortable environment for mathematical communication is vital to the success of mathematical discourse. An environment is conducive to sharing ideas will improve the quality and quantity of discussion, debate in the classroom (Brown \& Campione, 1994). Of great importance is building student conversation as a class norm, both in small groups and classes
(Silver, \& Smith, 1997). Communication in small groups can be stimulated by grouping student group goals, continuing encouragement to work and talking together, and strengthening the importance of each student's contribution (Brophy, 1999).

- Ask students to explain and justify their thinking Building an inquiry environment in a math class involves getting students to share their strategies, asking questions, and "thinking hard" (Cobb, Wood, Yackel, \& McNeal, 1992; Grouws \& Cebulla, 2000). By making their public thoughts, students may negotiate the meaning of mathematical ideas with other students, and defend and justify their reasons so that they can convince others through the legitimacy of their ideas. They negotiate and justify this process, students are often motivated to think deeper about their ideas and ideas of their classmates (Bauersfeld, 1995; Yackel \& Cobb, 1996)

- Encourage students to actively process the ideas of one of their friends.

The effectiveness and significance of mathematical discourse are to require students to listen carefully to the thoughts of others and to process and understand the ideas of other friends (Brown \& Campione, 1994). Classroom activities should be set up to ensure that students have enough time and encouragement to process other people's ideas.

Because the discussion helps students to summarize and synthesize the mathematics they are studying, the use of student thinking is an important element in mathematical discourse. When teachers help students build their thinking through conversation, misconception becomes more apparent, both for teachers and students and at the same time conceptual and procedural knowledge deep. At that time, the teacher must be an active listener in order to make decisions to be taken in facilitating the conversation.

\section{RESEARCH METHOD}

This research is in the form of learning device development (lesson plan and student worksheet) potentially mathematical discourse for SMP mathematics teacher. The research method used is descriptive. Research activities include: identification of problems through questionnaires, observation, and interviews; teacher training; teachers develop learning tools; validation; and enhancement of the device by the teacher. 


\section{Journal of Education, Teaching and Learning \\ Volume 2 No 2 September 2017. Page Number 177-182 \\ p-ISSN: 2477-5924 e-ISSN: 2477-4878}

The subjects of the research were Junior Junior High School teachers in several sub-districts in the border region of Sambas-Sarawak district, namely: Kec. Keramat Bay, Kec. Galing, Tangaran Sub-district, Paloh Sub-district, which is 25 people. Study time is academic year 2014/2015.

Instruments used in this research are questionnaire, observation sheet, learning device (lesson plan and student worksheet). Interviews were conducted during the preliminary study to find out what the implementation of the lesson was. The observation sheet is used to determine the implementation of the lesson during the limited trial. Learning tools are the necessary tools and developed to implement the learning, in this case, is lesson plan and student worksheet. Findings or facts about how the current learning is carried out, as well as what kind of tools used and developed are analyzed descriptively qualitatively. Learning result data is analyzed quantitatively.

\section{RESULT AND DISCUSSION}

A preliminary study was conducted to gain information on the opportunities and abilities of SMP mathematics teachers in the border region of SambasSarawak district related to mathematical discourse. Activities undertaken are to provide questionnaires, conduct interviews, and review documents (lesson plan) used by teachers in the field.

The results of the questionnaire can be seen in Table 1 below:

Table 1

Need assessment Mathematical Discourse

\begin{tabular}{|c|c|c|c|}
\hline Statements & $\begin{array}{c}\text { Agree } \\
(\%)\end{array}$ & $\begin{array}{l}\text { Doubt } \\
(\%)\end{array}$ & $\begin{array}{c}\text { Disagree } \\
(\%)\end{array}$ \\
\hline $\begin{array}{l}\text { 1. The method of teaching mathematics used } \\
\text { so far is the lecture / expository method }\end{array}$ & 75 & 0 & 25 \\
\hline $\begin{array}{l}\text { 2. In mathematics learning, teachers should } \\
\text { explain concepts and examples, after } \\
\text { which assign tasks to students }\end{array}$ & 91,7 & 0 & 8,3 \\
\hline $\begin{array}{l}\text { 3. Mathematical learning with class or } \\
\text { cooperative discussion is less effective } \\
\text { because it takes a lot of time }\end{array}$ & 25 & 50 & 25 \\
\hline $\begin{array}{l}\text { 4. The main thing in the process of learning } \\
\text { mathematics is that students can complete } \\
\text { the practice questions quickly and } \\
\text { correctly according to the way they are } \\
\text { taught }\end{array}$ & 75 & 0 & 25 \\
\hline $\begin{array}{l}\text { 5. The term discourse in mathematics } \\
\text { learning has never been heard }\end{array}$ & 83,3 & 8,3 & 8,3 \\
\hline $\begin{array}{l}\text { 6. In every learning mathematics there is } \\
\text { always a conversation between students } \\
\text { and students, as well as between teachers } \\
\text { with students }\end{array}$ & 100 & 0 & 0 \\
\hline $\begin{array}{l}\text { 7. The "why" or "how" questions rarely do } \\
\text { I ask students in the learning process } \\
\text { because it is too difficult for my students }\end{array}$ & 25 & 25 & 50 \\
\hline
\end{tabular}

Table 1 above shows that lessons learned tend to be conventional (more predominantly teachers) and provide less space for discussion, between students and students and teachers. This is evident from item 1 and item 2 . It is reinforced item 3 where a small fraction of respondents disagree that class or cooperative discussion is less effective because it takes a lot of time. Item 4 illustrates that respondents tend to prioritize results rather than develop students' communication skills through conversation or discourse. Although in every learning there is always a conversation between students with students and between students and teachers (item 5), but conversations that occur are just regular questions, not conversations that explore students' understanding. This is reflected in item 6 where there are still some respondents who rarely ask questions "why" or "how" in the learning process.

The results of interviews with some respondents revealed that the teaching methods that are often used in learning mathematics are the method of lectures and FAQs (expository), while class discussions are rarely used. In learning respondents always use student worksheet. Although most of the student worksheet used is made by the publisher, there are also respondents who make their own student worksheet. Judging from the questions given, the student worksheet from the publisher and the homemade worksheet student tend to present routine questions, not those that demand high ability, for example: non-routine or open ended questions.

Monitoring of lesson plan used, some respondents use lesson plan downloaded. This is seen in the core activities. In exploration activities, written among others:

- The material that is learned by applying the principles of alam takambang that means learning from various sources

- Using a variety of learning approaches, learning media, and other learning resources

In written elaboration activities, teachers:

- Facilitate learners through assignments, discussions, and others to come up with new ideas both orally and in writing.

- Facilitate learners in cooperative and collaborative learning

What is written, describes that the activities undertaken are still general (not specific). In addition, in contrast to the results of questionnaires and interviews that teachers rarely use a cooperative model or discussion in implementing learning process.

The other respondents tried to make lesson plan itself. In the core activities written: 
- Discuss two real or congruent builds through a flat-build model

- Teacher explains the corresponding and comparable sides

- Teacher explains two equally large angles of two awake and congruent builds

- Students are given practice questions.

What written above illustrates that the learning of mathematics that occurs more dominated teachers. Students only listen to the teacher's explanation and then do the exercises given.

Development of Learning Tools by Teachers

Because the term math discourse is something new (rarely heard) by teachers, the workshop activity begins with an explanation of "what, why, and how mathematical discourse". After that, the teachers in groups were asked to make lesson plan and student worksheet reflecting the occurrence of mathematical discourse in the learning process.

\section{Validation Results}

The tools produced by the teachers are further validated by 2 (two) lecturers of mathematics education with the format of the assessment (attached):

Based on the format, the following presented the results of lesson plan validation especially on the aspects of mathematical discourse (points $8,9,10$, and 11):

Table. 2

Validation Results of Lesson Plan

\begin{tabular}{lccccccccc}
\hline \multirow{2}{*}{ Group } & \multicolumn{4}{c}{ Validator 1 } & \multicolumn{5}{c}{ Validator 2 } \\
\cline { 2 - 18 } & $\mathbf{8}$ & $\mathbf{9}$ & $\mathbf{1 0}$ & $\mathbf{1 1}$ & $\mathbf{8}$ & $\mathbf{9}$ & $\mathbf{1 0}$ & $\mathbf{1 1}$ \\
\hline Group 1 & $\mathbf{C}$ & $\mathbf{B}$ & $\mathbf{K}$ & $\mathbf{K}$ & $\mathbf{B}$ & $\mathbf{C}$ & $\mathbf{C}$ & $\mathbf{B}$ \\
Group 2 & K & K & K & K & B & C & C & C \\
Group 3 & C & B & K & C & C & B & C & B \\
Group 4 & B & B & B & B & B & B & B & B \\
Group 5 & K & C & K & C & C & C & C & C \\
Group 6 & K & K & K & K & C & C & C & C \\
Group 7 & C & B & C & C & B & C & B & B \\
\hline
\end{tabular}

Based on Table 2 above it appears that only one group (group 4) shows lesson plan which describes the discourse well, where both validators give the same (good) value for all points. This means that most teachers in designing mathematical discourse are still just regular questions, not raising questions that describe the occurrence of debates among students to achieve an understanding of mathematical concepts.

The validation results of the questions (student worksheet) in points 3.4 , and 5 are as follows:

Table 3

Results of Problem Validation

\begin{tabular}{lcccccc}
\hline \multirow{2}{*}{ Group } & \multicolumn{3}{c}{ Validator 1 } & \multicolumn{3}{c}{ Validator 2 } \\
\cline { 2 - 7 } & 3 & 4 & 5 & 3 & 4 & 5 \\
\hline Group 1 & C & C & B & K & C & B \\
Group 2 & SK & SK & B & SK & SK & B \\
Group 3 & C & K & B & C & C & B \\
Group 4 & K & K & B & SK & SK & B \\
Group 5 & C & K & B & B & K & B \\
Group 6 & SK & SK & B & SK & SK & B \\
Group 7 & K & K & B & K & K & B \\
\hline
\end{tabular}

Based on Table 3, it shows that the problems developed in the student worksheet tend to be less encouraging the occurrence of discourse. This is because the problems made by the teachers are still routine matters.

\section{RESULT AND DISCUSSION}

Based on the results obtained from previous exposure that the learning process of mathematics is still dominated by teachers. Even if there is a conversation between the teacher and the student, the conversation is just a casual conversation, not a conversation that explores students' understanding especially through the "why?" And "how?" Questions. In addition, the questions given to students in student worksheet tend to be routine. This looks good from the results of preliminary studies, as well as from the teacher-generated tools. There are several things that cause it.

First, the teacher still considers that the process of teaching and learning is transferring knowledge to the students. The teacher embraces the flow of behavioral psychology wherein teaching the teacher explains the concept followed by giving examples of further questions the teacher gives a matter of exercises for students to do. Such learning tends not to develop all potential students. To develop students' mathematical communication skills, should the teacher's learning process provide space for discussion between teachers and students as well as between students and students. Through mathematical discourse, teachers can ask students to be involved in expressing their ideas or opinions, for example through revoicing, restate, add on, press for reasoning, and wait time. example:

- "Did you say ... .. Is that what you meant?" (Revoicing)

- "Can you repeat what he just said in your own word?" (Restate)

- "Would someone like to add on?" Or "what do others think about this question?" (Add on)

- "Do you agree with his reasoning? Why or why not? "(Press for reasoning)

- "What conclusions can we draw? (wait time) Chapin, O'Connor, \& Anderson, 2009) 


\section{Journal of Education, Teaching and Learning \\ Volume 2 No 2 September 2017. Page Number 177-182 \\ p-ISSN: 2477-5924 e-ISSN: 2477-4878}

Second, teachers still think that the process of learning mathematics is the process of silence (silent), without having to go through the conversation between one with another. This is seen from the results of the questionnaire item 4 , that the main thing in the process of learning mathematics is that students can solve the problem quickly and correctly according to the way they are taught. In mathematics learning the main thing is understanding the concept, and one of the efforts is through conversation with each other. According to Principles and Standards for School Mathematics (PSSM) from NCTM (2000) that communication is an essential part of mathematics and mathematics education because it is "way of sharing ideas and clarifying understanding. Through communication, ideas become objects of reflection, refinement, discussion, and amendment. The communication process helps build meaning and permanence for ideas and make them public ".

Third, teachers are already in a safe zone so they do not have to bother making lesson plan let alone designing a lesson plan that contains mathematical discourse. So also with the questions given in student worksheet, no need to bother thinking about non-routine matter especially about open-ended. Yet the exits in the test are mostly routine matters.

\section{CONCLUSIONS AND SUGGESTIONS}

Based on the analysis in the previous chapter can be concluded some matters relating to research problems as follows:

- The opportunities and abilities of teachers to develop productive discourse in mathematics learning so that students' communication skills are improved is that:

1. In the process of learning mathematics, teachers do lecture and question and answer methods.

2. In every math learning, there is always a conversation between teacher-students, as well as between students, but some teachers rarely use the "why" or "how" questions.

3. Student Worksheet used by teachers, both from publishers and homemade rarely contain non-routine questions or open ended.

- The feasibility level of teacher-made learning tools that can generate productive discourse is relatively less. This is because:

1. Lesson Plan: as large lesson plan created by the teacher to load scenario of conversation between teacher and student, but mostly just regular questioning, have not led to the debate between one with another so that understanding becomes deeper. If any elements add on, or press for reasoning, but only slightly. The other elements have not been so visible.

2. Student Worksheet: most of the student worksheet created by the teacher is a matter of regular story (routine). Almost no one makes non-routine questions, let alone the matter of open ended that allows the occurrence of mathematical discourse.

In connection with the results obtained, it is advisable:

First, the assumption of teaching is the transfer of knowledge to students need to be reviewed by the teacher to towards the development of all potential students. To develop students' mathematical communication skills, teachers need to show more moves (talk moves) in mathematical conversation scenarios, such as: revoice, restate, add on, press for reasoning, and wait time. This is expected to encourage students to engage in discussions.

Second, the assumption of the learning process of mathematics is a quiet process that needs to be reviewed by the teacher to get an understanding of the concept through the conversation between one another. For that teachers need to have the skills to ask questions so that students can make more courage to express opinions.

Third, teachers need to improve their commitment to teachers who have the ability to design lesson plan with potential mathematical discourse and student worksheet which contains nonroutine and open ended questions. With this ability is expected to occur productive mathematical discourse.

\section{REFERENCES}

Bauersfeld, H (1995). Structuring the Structures. In L.P. Steffe \& J. Gale (eds), Constructivism and Education. Hillsdale, NJ: Lawrence Erlbaum Associates.

Brophy, J (1999). Teaching. In H. Walberg (ed), Educational Practices Series-1. Geneva: International Academy of education. Available online at http://www.ibe.unesco.org.

Brown, A.L, \& Campione, J.C (1994). Guided discovery in a community of learners. In K. McGilly (Ed). Classroom lesson integrating cognitive theory and classroom practice. Cambridge, MA: MIT Press.

Chapin, O'Connor, Anderson (2003). Classroom Discussion Using Math Talk to Help Students 
Learn, grades 1-6. Sausalito CA: Math Solution Publications.

Clark, K, Jacob, J, Pittman, M.E, Borko, H (2005). Strategies for Building Mathematical Communication in the Middle School Classroom: Modeled in Profesional Development, Implemented in the Classroom, Current Issues in Middles Level Education. 11(2). 1-12.

Cobb, P, Wood, T, Yackel, E, \& Mc Neal (1992). Characteristics of Classroom mathematics Tradition: An Interactional Analysis. American Educational Research Journal, 29 p. 573-604).

Cohen, E.G (1984). Taking and Working Together: Status Interaction and Learning. In Peterson, L.S Wilkinson, \& M. Hallinan (Eds). Instructional Groups in the Classroom: Organization and Processes. Olando, FL: Academic Press.

Grouws, D.A, \& Cebulla, K.J (2000). Improving student achievement in mathematics: Recommendations for the classroom (Report no.SE 064318. Columbus, OH: ERIC Clearinghouse for Science, Mathematics, and Environmental Education.

NCTM (2000). Principle and Standards for School Mathematics. Virginia: NCTM.

Peressini, D \& Knuth, E (1998). Why are you talking when you could be listening? The role of discourse and reflection in the professional development of a secondary mathematics teacher. Teaching and Teacher Education, 14 (1), 107-125.

Silver, E.A., \& Smith, M.S (1997) Implementing reform in the mathematics classroom: Creating mathematical discourse communities. in Reform in math and science education: Issue for teacher. Columbus, $\mathrm{OH}$ : Eisenhower National Clearinghouse.

Stein, M.K, Smiths, M.S, Henningsen, M.A, \& Silver, E.A (2000). Implementing standardsbased mathematics instruction. New York: Teacher College Press.

Whitenack, J \& Yackel, E (2002). Making mathematical arguments in the primary grades: The importance of explaining and justifying ideas. Teaching Children Mathematics, 8(9), 524-527.

Yackel, E \& Cobb, P (1996). Sociomathematical norm, argumentation, and autonomy in mathematics: Journal for Research in Mathematics Education, 27, 458-477. 